\title{
Effects of seed and vegetative stage cysteine treatments on oxidative stress response molecules and enzymes in Ocimum basilicum L. under cobalt stress
}

\author{
M. R. Azarakhsh *, Z. Asrar, H. Mansouri \\ Department of Biology, Faculty of Science, Shahid Bahonar University, Kerman, Iran \\ *Corresponding Author: m.r.azarakhsh66@gmail.com
}

\begin{abstract}
In this research, the effects of seed and vegetative stage cysteine treatments on the oxidative stress response of molecules and enzymes in Ocimum basilicum L. under cobalt stress were studied. Parameters such as proline content, lipid peroxidation, leaf protein content, ascorbate peroxidase, catalase, phenylalanine ammonia-lyase and polyphenoloxidase activity were measured. Research was conducted in two separate trials including seed treatment and the treatment of plant at vegetative stage. In both cases, cobalt treatment was done in vegetative stage. Concentrations of $0,0.5$ and $2.5 \mathrm{mM}$ cysteine and 0,100 and $500 \mu \mathrm{M}$ cobalt were used. Higher concentrations of cobalt increased MDA, other aldehydes, proline content and activity of CAT, APX, and PPO compared with the control (without cobalt and cysteine). Cobalt stress decreased leaf protein content compared with the control. Seed treatment with cysteine reduced the MDA, other aldehydes, proline, leaf protein content and APX activity of plants compared to plant treated with cobalt and without cysteine. Plant treatment with cysteine at vegetative stage caused an increase in leaf protein and a decrease in MDA, other aldehydes, proline, content and activity of CAT, APX and PPO. The results showed that seed treatment with cysteine could alleviate cobalt stress effects in lower concentrations while cysteine applied in vegetative stage was more effective at higher concentrations of cobalt. Based on these results probably cysteine due to protection of membrane decreased oxidative stress created by cobalt treatment.
\end{abstract}

Keywords: Basil, cobalt, cysteine, heavy metal

\section{Introduction}

Heavy metals (a group of metals with density higher than $5.0 \mathrm{~g} \mathrm{~cm}^{-3}$ ) are components of the biosphere, and thus occur naturally in soils and plants. In most terrestrial ecosystems, both the underlying rock material and the atmosphere are two main natural sources of heavy metals. While volcanoes and continental dusts are at the origin of heavy metals in the atmosphere, heavy metals in soils are mainly due to human activities such as agricultural use of fertilizers, agrochemical compounds or sewage 
sludges, as well as activities like mining, combustion of fossil fuels and metals-working industries (Page et al., 2006). Plants are in direct contact with soil, which is the main source of heavy metal ions for the living organisms. As a response to the toxic action of metals various protective mechanisms have been elaborated in plants (Kleizaite et al., 2004; Hasani et al., 2012). Cobalt is an essential component of several enzymes and co-enzymes. Depending on the conditions and concentrations of cobalt in soil rhizosphere and plant, growth and metabolism are affected at different levels. High concentrations of cobalt are toxic for humans, plants and animals (aquatic and terrestrial). Plant chlorosis and decreased chlorophyll concentration are frequent incidents after plants exposure to toxic concentrations of metals, including cobalt (Kleizaite et al., 2004; Shaibur et al., 2013).

Cysteine is an $\alpha$-amino acid the thiol side chain in cysteine often participates in enzymatic reactions. In addition to its structural role in proteins, cysteine functions as a precursor for essential biomolecules, such as vitamins and co-factors, antioxidants, such as glutathione, and many defence compounds, such as glucosinolates and thionins (Alvarez et al., 2012) Also cysteine is involved in the complexion of the cobalt (Oven et al., 2002). Cysteine is synthesized in plants in the cytosol, plastids and mitochondria by the sequential action of the enzymes serine acetyltransferase (SAT, EC 2.3.1.30), which synthesizes the intermediary product O-acetylserine (OAS), and O-acetylserine(thiol)lyase (OASTL, EC 2.5.1.47), which combines a sulfide molecule with an OAS molecule to produce cysteine (Alvarez et al., 2012). Cysteine is the precursor molecule for the synthesis of glutathione (GSH), the predominant nonprotein thiol, which plays an important role in plant stress responses. GSH has been implicated in plant responses to toxic levels of heavy metals, as it is the precursor for the synthesis of phytochelatins (PCs), the thiolate peptides involved in the detoxification of heavy metals. PCs bind toxic heavy metal ions, and these complexes are transported into the vacuole by an ABC-type transporter (Dominguez-Solis et al., 2004). In plants, proline is generally synthesized from glutamate. Proline accumulation has also been proposed as a mechanism of storage of excess nitrogen. Many plants accumulate high concentrations of proline when treated with toxic heavy metals (Bassi and Sharma, 1993).

Basil is native to Asia (Iran, India, Pakistan, Thailand, and other countries) and growing in tropical and sub-tropical regions. Basil herb contains natural antioxidants and therefore can provide protection against free radicals. Basil is cultivated in agro climes between 7 to $27{ }^{\circ} \mathrm{C}$, with 0.6 to $4.2 \mathrm{~m}$ annual precipitation and soil $\mathrm{pH} 4.3$ to 8.2 (Makri and Kintzios, 2008).

In this study the effect of different concentrations of the amino acid cysteine in two group seed treatment and the treatment of vegetative stage on oxidative stress response molecules and enzymes were studied. In this regard, parameters such as MDA and other aldehydes, proline content, protein content and activity of CAT, APX, PAL and PPO were measured.

\section{Materials and Methods}

\subsection{Plant material}

Seeds of the basil (Ocimum basilicum L) were obtained from Pakan seed Company. Seeds were disinfected with $0.5 \%$ sodium hypochlorite for a minute and then were washed twice with distilled water. Seeds were sown in plastic pots $(15 \times 15 \mathrm{~cm})$ filled with perlite and were Maintained in greenhouse at $21 / 18^{\circ} \mathrm{C}$ in a $16 / 8$ light/dark photoperiod. Two seeds were planted in per 
pot as two samples. The pots were irrigated daily with $60 \mathrm{ml}$ half-strength Hoagland solution for 1 month.

In the first experiment, seeds were pre-treated in a solution of cysteine (L-Cysteine, Merck, for biochemistry) at concentrations of $0,0.5$ and $2.5 \mathrm{mM}$ for $24 \mathrm{~h}$, then washed three times with double distilled water and thereafter, cultured in perlite. Plants at the three pairs of leaves stage were treated with different concentrations of cobalt nitrate $(0,100$ and $500 \mu \mathrm{M})$ for 10 days.

In the second experiment, seeds were disinfected and then washed three times with double distilled water and cultured in pots. These plants were treated at vegetative stage with cysteine at concentrations of 0, 500 and $2500 \mathrm{mM}$ during 10 days contemporary with cobalt treatment (at concentrations similar to the first test). After 10 days, samples were harvested for biochemical and physiological analyses.

\section{2 .Proline content}

Free proline was determined according to Bates et al (1973). Shoot samples $(0.5 \mathrm{~g})$ from each group were homogenized in $3 \%(\mathrm{w} / \mathrm{v})$ sulfosalicylic acid and then the homogenate was centrifuged. The mixture was heated at $100{ }^{\circ} \mathrm{C}$ for $1 \mathrm{~h}$ in a water bath after the addition of acid ninhydrin and glacial acetic acid. The reaction was then stopped in an ice bath. The mixture was extracted with toluene and the absorbance of the fraction with toluene aspired from liquid phase was read at $520 \mathrm{~nm}$. The proline concentration was determined using a calibration curve and expressed as $\mathrm{mg} \mathrm{g}^{-1} \mathrm{FW}$ (Bates et al., 1973).

\subsection{Lipid peroxidation}

The level of lipid peroxidation in plant tissues was measured by determination of malondialdehyde
(MDA) (Heath and Packer, 1968) and other aldehydes (Meir et al., 1992), which are known to be breakdown products of lipid peroxidation. A 0.1 $\mathrm{g}$ of the shoot samples was homogenized in $10 \mathrm{ml}$ of $0.1 \%$ TCA and centrifuged at $10,000 \times \mathrm{g}$ for 15 min. One $\mathrm{ml}$ of supernatant was then vortexed with $4 \mathrm{ml}$ of $20 \%$ TCA containing $0.5 \%$ 2-thiobarbituric acid (TBA), and the solution was heated for $30 \mathrm{~min}$ at $90{ }^{\circ} \mathrm{C}$. The sample was cooled on ice for $5 \mathrm{~min}$ and recentrifuged for $10 \mathrm{~min}$ at $10,000 \times \mathrm{g}$. The nonspecific absorbance of supernatant at $600 \mathrm{~nm}$ was subtracted from the maximum absorbance at 532 $\mathrm{nm}$ for MDA measurement, and at $455 \mathrm{~nm}$ for other aldehydes. For the calculation of MDA and other aldehydes, an extinction coefficient $(\mathcal{E})$ of $1.55 \times 10^{5}$ $\mathrm{M}^{-1} \mathrm{~cm}^{-1}$ was used at $532 \mathrm{~nm}$ for MDA and $(\varepsilon)$ of 0.457 $\times 10^{5} \mathrm{M}^{-1} \mathrm{~cm}^{-1}$ was used at $455 \mathrm{~nm}$ at the average of e obtained for five other aldehydes (propanal, butanal, hexanal, heptanal and propanal dimethylacetal). Results were expressed as $\mu \mathrm{M} \mathrm{g}^{-1} \mathrm{FW}$.

\subsection{Preparation of extracts for enzyme assays and protein determination}

Frozen shoot samples $(0.5 \mathrm{~g})$ were homogenized in $2.5 \mathrm{ml}$ of $50 \mathrm{mM}$ phosphate buffer $(\mathrm{pH} 7.2)$ containing $1 \mathrm{mM}$ ethylenediamine tetra acetic acid (EDTA), $1 \mathrm{mM}$ phenylmethanesulfonyl fluoride (PMSF) and $1 \%$ polyvinylpyrrolidone (PVP). The homogenate was centrifuged at $14,000 \times \mathrm{g}$ for $15 \mathrm{~min}$ at $4^{\circ} \mathrm{C}$ and the clear supernatant was used directly for the assay of enzyme activity and estimation of protein. Activity of enzyme was determined at $25^{\circ} \mathrm{C}$ using a spectrophotometer. The supernatant was used for measurement of total soluble protein according to Bradford (1976) and expressed in $\mathrm{mg} \mathrm{g}^{-1} \mathrm{fw}$. Bovine serum albumin was used as standard (data not shown) (Bradford, 1976). 


\subsection{Ascorbate peroxidase (APX) (EC 1.11.1.1)}

Ascorbate peroxidase activity was measured using the method of Nakano and Asada (1981). The reaction mixture consisted of $50 \mathrm{mM}$ potassium phosphate buffer ( $\mathrm{pH} 7.0$ ) containing $0.5 \mathrm{mM}$ ascorbic acid, 0.15 $\mathrm{mM} \mathrm{H} 2 \mathrm{O} 2,0.1 \mathrm{mM}$ EDTA and $50 \mu 1$ enzyme extract. Decrease in absorbance at $290 \mathrm{~nm}$ was considered as oxidation of ascorbic acid and was followed 2 min after starting the reaction. One unit of APX oxidized $1 \mu \mathrm{M}$ of ascorbic acid in $1 \mathrm{~min}$ (Nakano and Asada, 1981).

\subsection{Catalase (CAT) (EC 1.11.1.6)}

Catalase activity was assayed using the method of Dhindsa et al (1981). The enzyme activity was estimated by monitoring the decrease in absorbance of $\mathrm{H}_{2} \mathrm{O}_{2}$ at $240 \mathrm{~nm}$. The assay solution contained 50 $\mathrm{mM}$ of potassium phosphate buffer $(\mathrm{pH}$ 7.0) and 15 $\mathrm{mM} \mathrm{H}_{2} \mathrm{O}_{2}$. The reaction was started by the addition of $100 \mu 1$ enzyme extract to the reaction mixture. The change in absorbance was followed 1 min after starting of the reaction. Unit of activity was taken as the amount of enzyme that decomposes $1 \mu \mathrm{M}$ of $\mathrm{H}_{2} \mathrm{O}_{2}$ in 1 min (Dhindsa et al., 1981).

\subsection{Phenylalanine ammonia-lyase (EC 4.3.1.5)}

Enzyme extract was prepared by homogenising $5 \mathrm{~g}$ for $2 \mathrm{~min}$ in $15 \mathrm{ml} 0.1 \mathrm{M}$ borate buffer ( $\mathrm{pH} 8.8$ ) containing $6 \mathrm{~g}$ PVP, $5 \mathrm{mM}$ mercaptoethanol, and $2 \mathrm{mM}$ EDTA according to the method of Cheng and Breen (1991). The homogenate was centrifuged for $20 \mathrm{~min}$ at $19000 \mathrm{~g}$ and the supernatant collected was used for determination of enzyme activity. PAL activity was measured by incubating $0.5 \mathrm{ml}$ supernatant with $2 \mathrm{ml} 0.1 \mathrm{M}$ borate buffer $(\mathrm{pH}$ 8.0) containing $3 \mathrm{mM} \mathrm{L}$-phenylalanine for $1 \mathrm{~h}$ at $30^{\circ} \mathrm{C}$. Increase in absorbance at $290 \mathrm{~nm}$, due to the formation of trans-cinnamate, was measured spectrophotometrically.
One unit of enzyme activity $\left(\mathrm{kat}=1 \mathrm{~mol} \cdot \mathrm{s}^{-1}\right)$ was defined as the amount of enzyme required for the formation of $1 \mu \mathrm{mol}$ of trans-cinnamate in $1 \mathrm{~min}$ under the assay conditions Control reactions contained only enzyme solution and buffer (Cheng and Breen 1991).

\subsection{Polyphenoloxidase (EC 1.10.3.1)}

Polyphenoloxidase activity was assayed using the method of Patra and Mishra (1979). The assay mixture contained: $300 \mu \mathrm{mol}$ phosphate buffer (pH 6.8), $5 \mu \mathrm{mol}$ pyrogallol, and $1 \mathrm{ml}$ enzyme extract. The amount of purpurogallin formed was determined from the absorption at $420 \mathrm{~nm}$. One unit of polyphenol oxidase activity was defined as that amount of purpurogallin formed which increases the absorption by 1 minute under the assay conditions described above (Patra and Mishra, 1979).

\subsection{Statistical analysis}

Data for each parameter were subjected to twoway ANOVA and significant differences between treatment means were determined by Duncan multiple range test (DMRT) using the SPSS software. Data are shown as means with three replicates and significance was determined at the $95 \%$ confidence (p 0.05) limits.

\section{Results}

\subsection{Malondialdehyde and other aldehydes}

Data presented in Figure 1 and 2 showed 100 and $500 \mathrm{mM}$ cobalt treatments significantly increased MDA and other aldehydes compared with the control (without cobalt and cysteine). Seeds treatment with cysteine in all levels significantly decreased MDA content compared with untreated-cysteine plants. Treatment of plants with cysteine at vegetative stage significantly decreased MDA compared with 
untreated-cysteine plants. In vegetative plants treated with $500 \mathrm{mM}$ cobalt, cysteine treatment significantly decreased other aldehydes compared with untreated- cysteine plants. Also in 100 and $500 \mathrm{mM}$ cobalt, seed treatment with cysteine significantly decreased other aldehydes compared with untreated-cysteine plants.

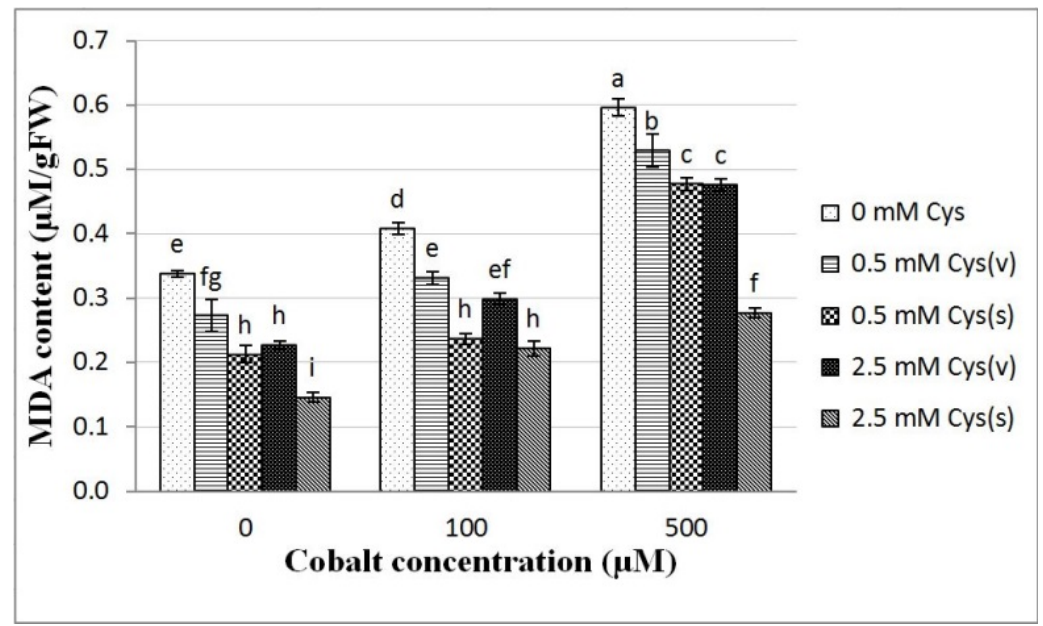

Figure 1. Effect of different concentrations of Co and cysteine on MDA content. Data are means of three replicates $\pm \mathrm{SE}$. The different letters indicate significant difference $(\mathrm{P} \leq 0.05)$ by Duncan test (v: vegetative stage treatment, s: seed treatment).

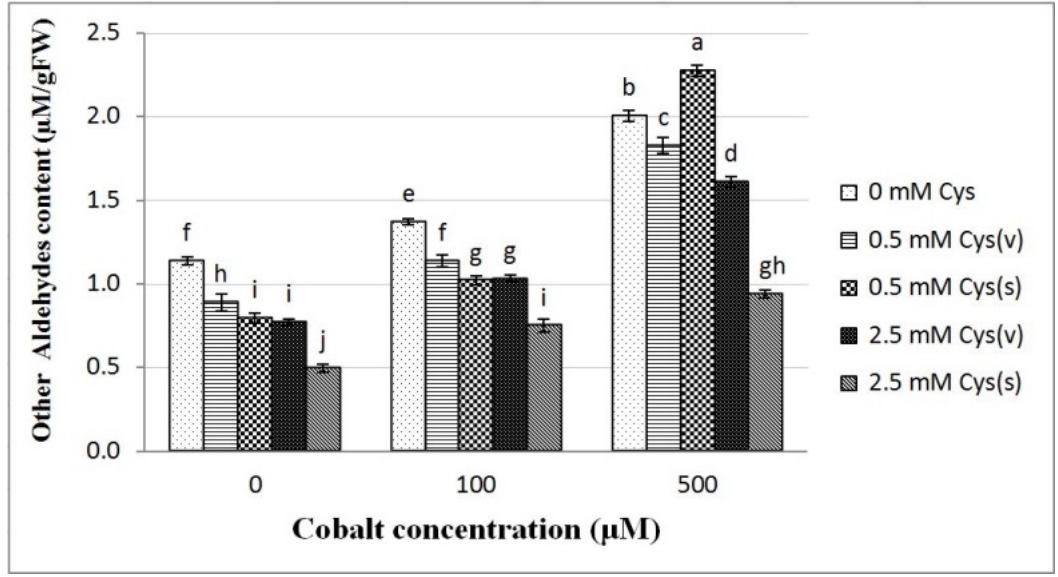

Figure 2. Effect of different concentrations of $\mathrm{Co}$ and cysteine on other aldehydes content. Data are means of three replicates \pm SE. The different letters indicate significant difference $(\mathrm{P} \leq 0.05)$ by Duncan test. (v: vegetative stage treatment, s: seed treatment) 


\subsection{Proline}

Cobalt in 100 and $500 \mathrm{mM}$ coblat significantly increased proline content compared with the control (without cobalt and cysteine) (Figure 3). Seed treatment with cysteine significantly increased the proline content. But with cobalt treatments, cysteine at all levels significantly decreased proline content compared with untreated-cysteine plants. Also vegetative stage of cysteine treatment significantly decreased proline content compared with untreatedcysteine plants.

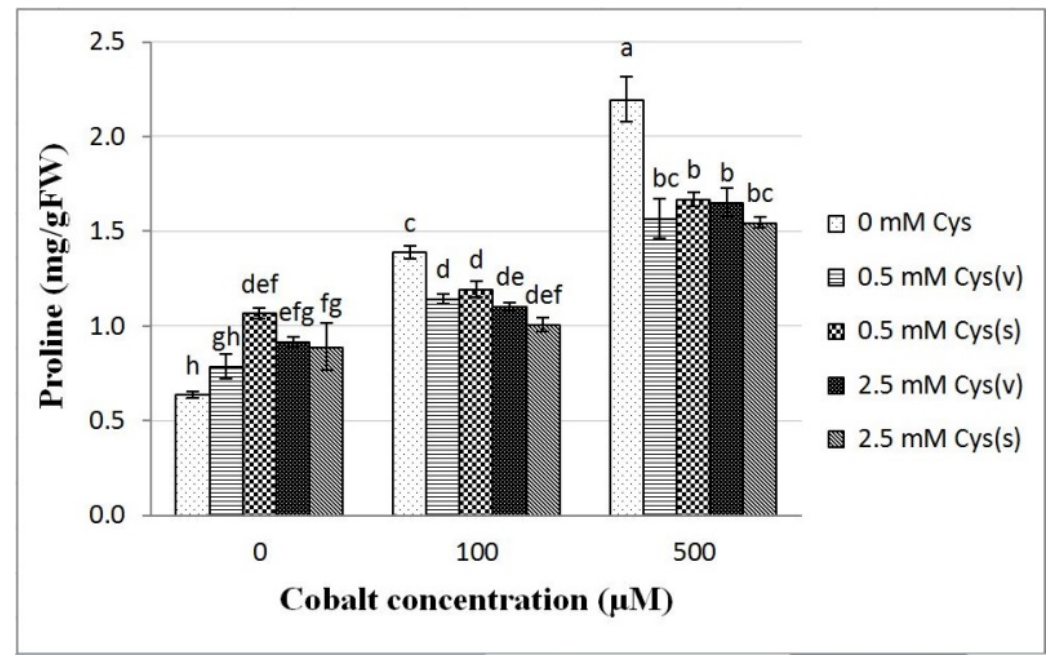

Figure 3. Effect of different concentrations of Co and cysteine on proline content. Data are means of three replicates \pm SE. The different letters indicate significant difference $(\mathrm{P} \leq 0.05)$ by Duncan test. (v: vegetative stage treatment, s: seed treatment)

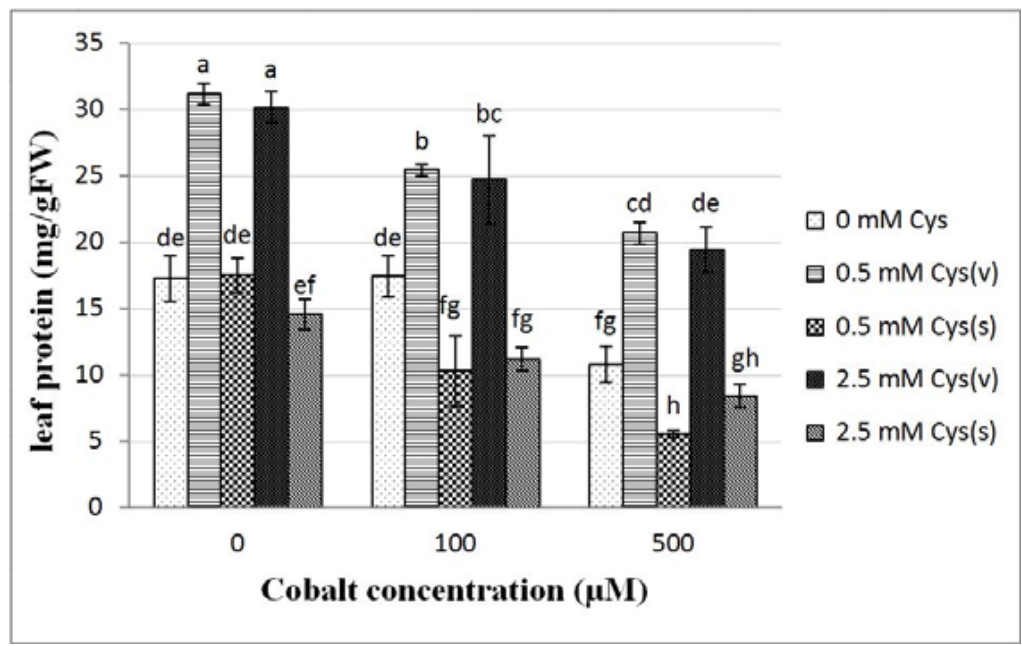

Figure 4. Effect of different concentrations of Co and cysteine on leaf protein content. Data are means of three replicates $\pm \mathrm{SE}$. The different letters indicate significant difference $(\mathrm{P} \leq 0.05)$ by Duncan test. (v: vegetative stage treatment, s: seed treatment) 


\subsection{Protein}

Cobalt in concentration of $100 \mathrm{mM}$ had no effect on leaf protein content but concentration of $500 \mathrm{mM}$ of cobalt reduced the leaf protein content (Figure 4). Vegetative plants treated with cysteine showed significantly increased in the leaf protein content. Data also revealed that seed treatment with cysteine at all levels significantly decreased leaf protein content in plants.

\subsection{Catalase (CAT) (EC 1.11.1.6)}

As it is shown in Figure 6 seed and vegetative plants treated with cysteine in all levels used showed significant increase in activity of CAT in samples without of cobalt. Cobalt in 100 and $500 \mathrm{mM}$ significantly increased activity of CAT compared with the control (Without cobalt and cysteine).

\subsection{Ascorbate peroxidase (APX) (EC 1.11.1.1)}

In samples without cobalt treatment, seed treatment of cysteine at a concentration of $2.5 \mathrm{mM}$ significantly increased the APX activity (Figure 5). Data presented in Figure 5 showed cobalt in 100 and $500 \mathrm{mM}$ significantly increased activity of APX compared with the control (Without cobalt and cysteine). Whereas seed treatment with cysteine in all levels significantly decreased activity of APX compared with untreated plants with cysteine. In vegetative plants treated with cysteine activity of APX significantly decreased compared with untreated-cysteine plants.

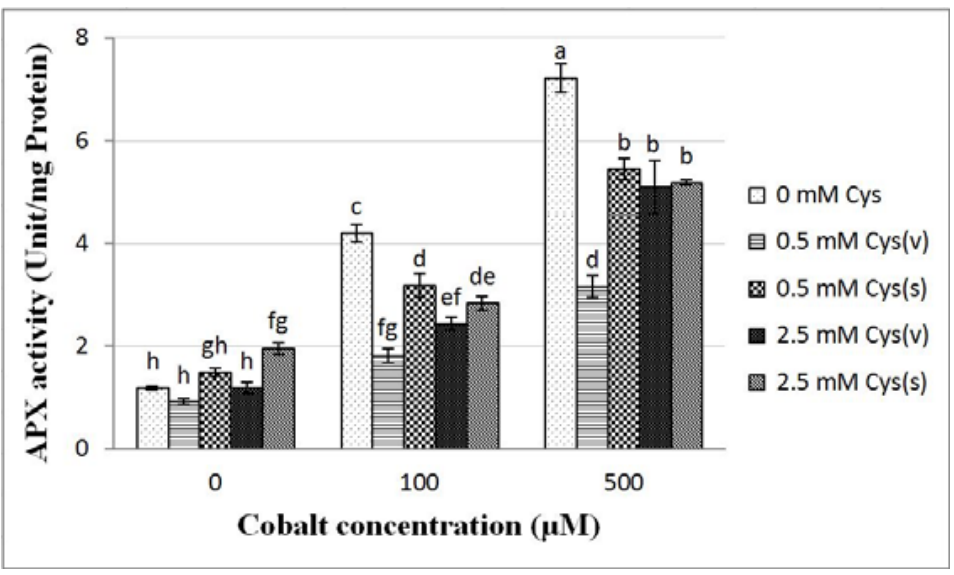

Figure 5. Effect of different concentrations of Co and cysteine on APX activity. Data are means of three replicates \pm SE. The different letters indicate significant difference $(\mathrm{P} \leq 0.05)$ by Duncan test. (v: vegetative stage treatment, s: seed treatment)

3.6. Phenylalanine ammonia-lyase (EC 4.3.1.5)

Cysteine treatment alone had not significant effect on PAL activity. Cobalt in $500 \mathrm{mM}$ concentration significantly promoted PAL activity compared with the control (Without cobalt and cysteine) (Figure 7). Data also showed that seed treatment with cysteine in all levels significantly increased 
PAL activity compared with untreated-cysteine plants. Treatment of vegetative plants with cysteine did not have significant effect on PAL activity.

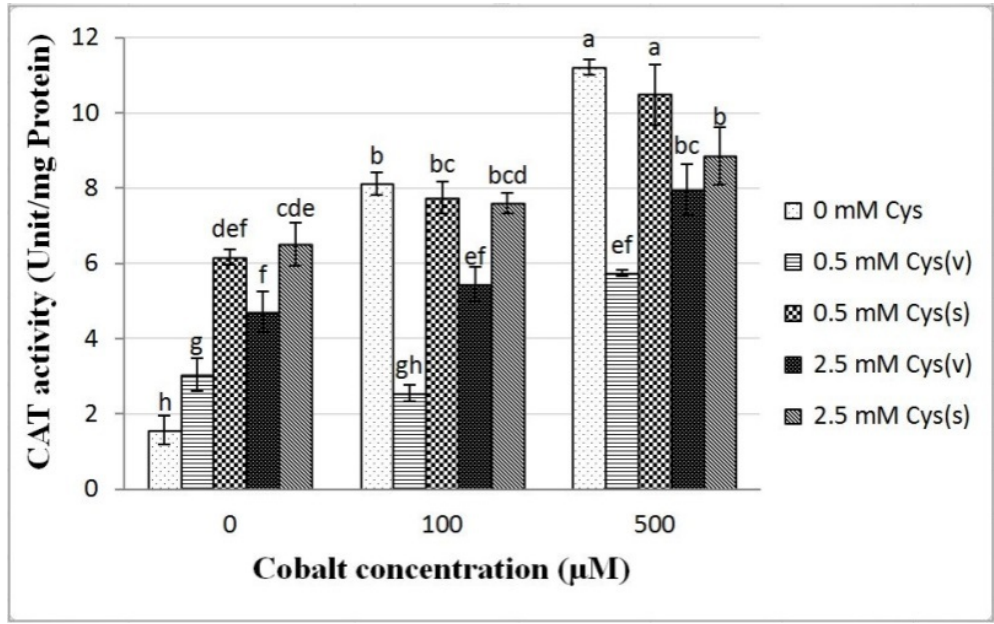

Figure 6. Effect of different concentrations of Co and cysteine on CAT activity. Data are means of three replicates \pm SE. The different letters indicate significant difference $(\mathrm{P} \leq 0.05)$ by Duncan test. (v: vegetative stage treatment, s: seed treatment)

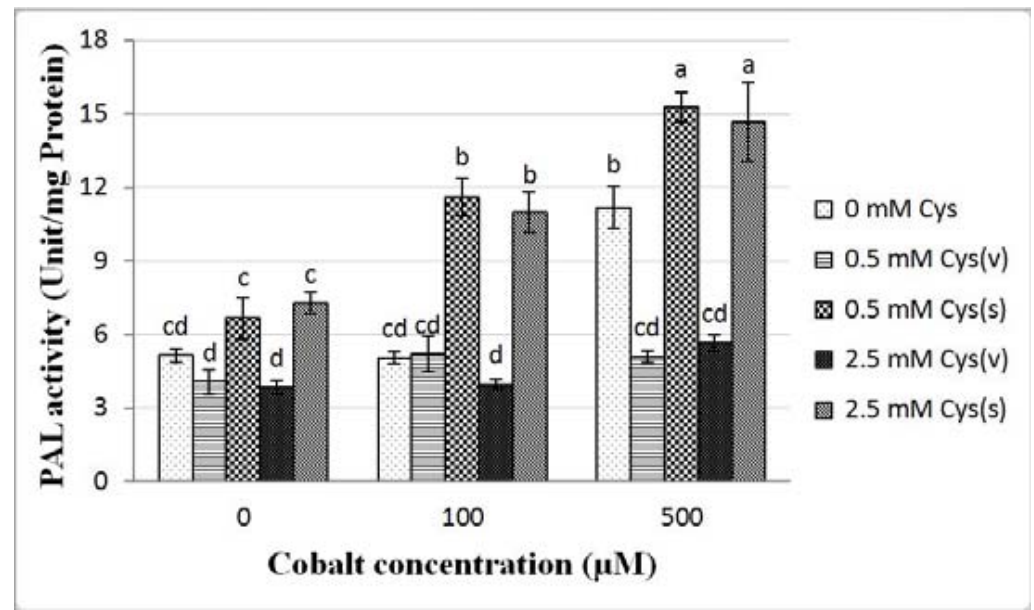

Figure 7. Effect of different concentrations of Co and cysteine on PAL activity. Data are means of three replicates \pm SE. The different letters indicate significant difference $(\mathrm{P} \leq 0.05)$ by Duncan test. (v: vegetative stage treatment, s: seed treatment) 


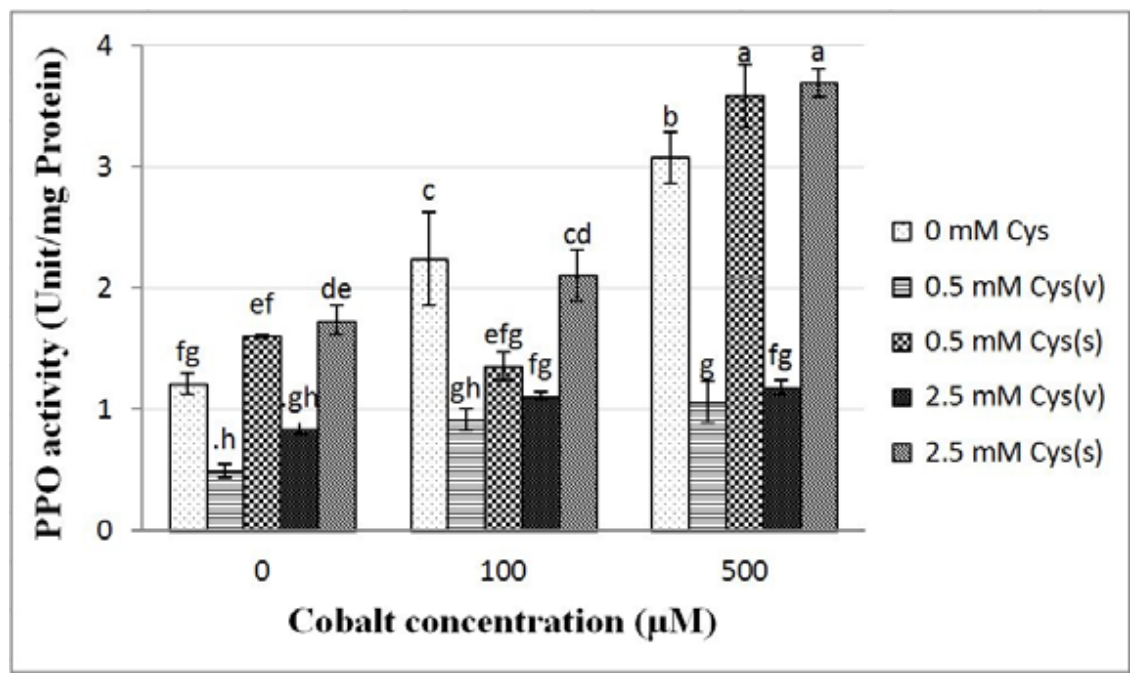

Figure 8. Effect of different concentrations of Co and cysteine on PPO activity. Data are means of three replicates $\pm \mathrm{SE}$. The different letters indicate significant difference $(\mathrm{P} \leq 0.05)$ by Duncan test. (v: vegetative stage treatment, s: seed treatment)

\subsection{Polyphenoloxidase (EC 1.10.3.1)}

As it is shown in Figure 8 application of 100 and $500 \mu \mathrm{M}$ cobalt significantly increase polyphenol oxidase activity. In samples without of cobalt, seed treatment with cysteine at a concentration of 2.5 $\mathrm{mM}$ significantly increased the polyphenol oxidase activity and cysteine treatment in vegetative stage at a concentration of $0.5 \mathrm{mM}$ significantly decreased the polyphenol oxidase activity. Also plants treated with cysteine at vegetative stage showed significant decrease in activity of PPO compared with untreatedcysteine plants. Seed treatment with cysteine unaffected in PPO activity compared with untreatedcysteine plants.

\section{Discussion}

So far, little research has been conducted on the effect of the amino acid cysteine on growth and biochemical parameters in plants. Zagorchev et al., (2013) reported that free cysteine increased in response to various abiotic stresses. Cysteine is strong chelator of heavy metal ions (Zagorchev et al., 2013) and it was indicated that cysteine was involved in the complexion of the cobalt (Oven et al., 2002). Thus to study the effect of cysteine on cobalt stress we designed this research.

Data presented showed cobalt significantly increased proline content in purple basil. Data also revealed that cysteine treatment (seed and vegetative stage) significantly decreased proline content. Increase in proline content in high level of cobalt has been reported in Cicer arietinum and Vigna unguiculata (Vijayarengan, 2011; Ali et al., 2010).

MDA and other aldehydes contents are routinely estimated parameter to assess the extent of oxidative stress (Bandeoglu et al., 2004). In this research cobalt significantly increased MDA and other aldehydes content in treated plants. Data also revealed that cysteine treatment of seed and vegetative plants significantly decreased MDA and other aldehydes in 
plants under cobalt stress. Increase in MDA content in high level of cobalt has been reported in Cicer arietinum and Phaseolus vulgaris (Zengin, 2013; Ali et al., 2010). According to our results cysteine treatment decreased malondealdehyde content in barley (Yi and Liu, 2007). Decreasing of malodealdehyde can be due to chelating effect of cysteine on cobalt, resulting to membrane conservation.

Our results showed cobalt significantly decreased leaf protein content. Data also revealed that cysteine treatment of seeds decreased leaf protein content, but cysteine treatment of vegetative plants promoted leaf protein content in all plants. Like our results, decrease in protein content in high level of cobalt has been reported in cowpea (Vigna unguiculata (L.) Walp.) (Vijayarengan, 2011). Unlike our results, (Gad and Kandil, 2008; 2012) notified an increase in protein content in high level of cobalt in Sweet potato roots (Ipomoea batatas L) and Coriander (Coriandrum sativum L.).

In higher plants, heavy metals induce oxidative stress by generation of superoxide radical $\left(\mathrm{O}_{2}^{\circ}\right.$, hydrogen peroxide $\left(\mathrm{H}_{2} \mathrm{O}_{2}\right)$, hydroxyl radical $\left(\mathrm{OH}^{\circ}\right)$, and singlet oxygen $\left({ }^{1} \mathrm{O}_{2}\right)$, collectively termed ROS (Reactive Oxygen Species). ROS can rapidly attack all types of biomolecules such as nucleic acids, proteins, lipids, and amino acids, leading to irreparable metabolic dysfunction and cell death. Therefore, the induction of antioxidant enzymes including CAT, and POD is an important protective mechanism to minimize oxidative damage in polluted environments (Zhang et al., 2007).

According to our results, cobalt increased activity of CAT, APX and PPO in purple basil. High level of cobalt increased peroxidase and ascorbate peroxidase activity in Brassica campestris (Sinha et al., 2012), peroxidase and polyphenoloxidase activity in Raphanus sativus (Jayakumar et al., 2007) and catalase, peroxidase and polyphenoloxidase activity in Vigna unguiculata (Vijayarengan, 2011).

Seed treatment with cysteine decreased activity of APX in purple basil. Also cysteine treatment of vegetative stage decreased activity of APX and PPO compared with untreated-cysteine plants. We did not find any report about the effect of cysteine on the activity of these enzymes. Probably cysteine decreased oxidative stress by chelating of cobalt, resulting to decline in antioxidant enzyme activity.

Plant phenolic compounds by inhibition of lipid peroxidation (by trapping the lipid alkoxyl radical), scavenging molecular species of active oxygen (with their ability to donate electrons or hydrogen atoms), chelation of metal ions and exposure as substrate of peroxidase enzyme, reduce oxidative damage (Michalak, 2006). Phenolic compounds synthetized from cinnamic acid by the action of 1-phenyloalanine ammonia-lyase (PAL) (Ec 4.3.1.5) (Michalak 2006; Dixon and Paiva 1995).

In this research cobalt promoted PAL activity in treated plants. Also seed treatment with cysteine increased PAL activity compared with untreatedcysteine plants.

\section{Conclusion}

Cobalt treatment at high levels (100 and $500 \mu \mathrm{M})$ increased MDA, other aldehydes, proline content and antioxidant enzyme activity (CAT, APX, PPO, PAL) of Ocimum basilicum L plants. Based on the present investigation, it can be concluded that the seed treatment with cysteine could alleviate cobalt stress effects in low concentrations of this heavy metal, while cysteine applied in vegetative stage was more effective at higher concentrations of cobalt. Probably cysteine due to protection of membrane decreased oxidative stress created by cobalt treatment. 


\section{References}

Ali, B.,Hayat, S.,Hayat, Q.,Ahmad, A. 2010. Cobalt stress affects nitrogen metabolism, photosynthesis and antioxidant system in chickpea (Cicer arietinum L.). Journal of Plant Interactions. 5, 223-231.

Alvarez, C.,Angeles Bermudez, M.,Romero, LC.,Gotor, C.,Garcia, I. 2012. Cysteine homeostasis plays an essential role in plant immunity. New Phytologist. 193, 165-177.

Bandeoglu, E.,Eyidogan, F.,Yucel, M.,Oktem, HA. 2004. Antioxidant responses of shoots and roots of lentil to NaCl-salinity stress. Plant Growth Regulation. 42, 69-77.

Bassi, R.,Sharma, SS. 1993. Changes in proline content accompanying the uptake of zinc and copper by Lemna minor. Annals of botany. 72, 151-154.

Bates, L.,Waldren, R.,Teare, I. 1973. Rapid determination of free proline for water-stress studies. Plant and Soil. 39, 205-207.

Bradford, MM. 1976. A rapid and sensitive method for the quantitation of microgram quantities of protein utilizing the principle of protein-dye binding. Analytical biochemistry 72 (1):248-254

Cheng, GW.,Breen, PJ. 1991. Activity of phenylalanine ammonia-lyase (PAL) and concentrations of anthocyanins and phenolics in developing strawberry fruit. Journal of the American Society for Horticultural Science. 116, 865-869.

Dhindsa, RS.,Plumb-Dhindsa, P.,Thorpe, TA. 1981. Leaf senescence: correlated with increased levels of membrane permeability and lipid peroxidation, and decreased levels of superoxide dismutase and catalase. Journal of Experimental Botany. 32, 93-101.
Dixon, RA.,Paiva, NL. 1995. Stress-induced phenylpropanoid metabolism. The Plant Cell. 7, 1085-1097.

Dominguez-Solis, JR., Lopez-Martin, MC.,Ager, FJ.,Ynsa, MD.,Romero, LC.,Gotor, C. 2004. Increased cysteine availability is essential for cadmium tolerance and accumulation in Arabidopsis thaliana. Plant Biotechnology Journal. 2, 469-476.

Gad, N.,Kandil, H. 2008. Response of sweet potato (Ipomoea batatas L.) plants to different levels of cobalt. Australian Journal of Basic and Applied Sciences. 2, 949-955.

Gad, N.,Kandil, H. 2012. Influence of cobalt nutrition on coriander (Cariandrum sativum L.) Herbs yield quantity and quality. Journal of Applied Sciences Research. 8, 5184-5189.

Hasani, M; Zamani, Z; Savaghebi, G y Fatahi, R. 2012. Effects of zinc and manganese as foliar spray on pomegranate yield, fruit quality and leaf minerals. J. Soil Sci. Plant Nut. 12(3) 471-480.

Heath, RL.,Packer, L. 1968. Photoperoxidation in isolated chloroplasts: I. Kinetics and stoichiometry of fatty acid peroxidation. Archives of Biochemistry and Biophysics. 125, 189-198.

Jayakumar, K.,Jaleel, CA.,Vijayarengan, P. 2007. Changes in growth, biochemical constituents and antioxidant potentials in radish (Raphanus sativus L.) under cobalt stress. Turkish Journal of Biology. 31, 127-136.

Kleizaite, V.,Cesniene, T.,Rancelis, V. 2004. The use of cobalt-induced chlorophyll morphoses for studying $\mathrm{Co}^{2+}$ interactions with cysteine and SOD. Plant Science. 167, 1249-1256.

Makri, O.,Kintzios, S. 2008. Ocimum sp.(basil): Botany, cultivation, pharmaceutical properties, and biotechnology. Journal of Herbs, Spices \& Medicinal Plants. 13, 123-150. 
Meir, S.,Philosoph-Hadas, S.,Aharoni, N. 1992. Ethylene-increased accumulation of fluorescent lipid-peroxidation products detected during senescence of parsley by a newly developed method. Journal of the American Society for Horticultural Science. 117, 128-132.

Michalak, A. 2006. Phenolic compounds and their antioxidant activity in plants growing under heavy metal stress. Polish Journal of Environmental Studies. 15, 523-530.

Nakano, Y.,Asada, K. 1981. Hydrogen peroxide is scavenged by ascorbate-specific peroxidase in spinach chloroplasts. Plant and Cell Physiology. $22,867-880$

Oven M, Grill E, Golan-Goldhirsh A, Kutchan TM, Zenk MH 2002. Increase of free cysteine and citric acid in plant cells exposed to cobalt ions. Phytochemistry 60, 467-474

Page, V.,Bayon, RCL.,Feller, U. 2006. Partitioning of zinc, cadmium, manganese and cobalt in wheat ( Triticum aestivum) and lupin (Lupinus albus) and further release into the soil. Environmental and experimental Botany. 58, 269-278.

Patra, HK.,Mishra, D. 1979. Pyrophosphatase, peroxidase and polyphenoloxidase activities during leaf development and senescence. Plant Physiology. 63, 318-323.

Shaibur, M. R; Adjadeh, T. A y Kawai, S. 2013. Effect of phosphorus on the concentrations of arsenic, iron and some other elements in barley grown hydroponically. J. Soil Sci. Plant Nutr. 13(1), 79-85.
Sinha, P.,Khurana, N.,Nautiyal, N. 2012. Induction of Oxidative Stress and Antioxidant Enzymes by Excess Cobalt in Mustard. Journal of Plant Nutrition. 35, 952-960.

Vijayarengan, P. 2011. Changes in growth, biochemical constituents and antioxidant potentials in cowpea (Vigna unguiculata (L.) Walp.) under cobalt stress. International Journal of Research in Environmental Science and Technology. 2, 74-82.

Yi, H-1.,Liu, J. 2007. Protective Effects of Cysteine Against $\mathrm{SO}_{2}$-induced Oxidative Damage in Barley. Journal -shanxi University Natural Science Edition. 30, 270-273.

Zagorchev, L.,Seal, CE.,Kranner, I.,Odjakova, M. 2013. A Central Role for Thiols in Plant Tolerance to Abiotic Stress. International journal of molecular sciences. 14, 7405-7432.

Zengin, F. 2013. Physiological behavior of bean (Phaseolus vulgaris L.) Seedlings under metal stress. Biological research. 46, 79-85.

Zhang, F-Q.,Wang, Y-S.,Lou, Z-P.,Dong, J-D. 2007. Effect of heavy metal stress on antioxidative enzymes and lipid peroxidation in leaves and roots of two mangrove plant seedlings (Kandelia candel and Bruguiera gymnorrhiza). Chemosphere. 67, 44-50 